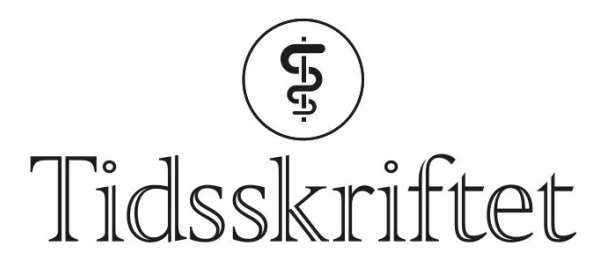

DEN NORSKE LEGEFORENING

\title{
En mann i 7o-årene med pleuravæske, knesmerter og dysartri etter åpen hjertekirurgi
}

NOE Å LARE AV

HALLVARD BERGE PEDERSEN*

hallvard.bp@gmail.com

Indremedisinsk avdeling

Oslo universitetssykehus, Ullevål sykehus

Hallvard Berge Pedersen er lege i spesialisering.

Forfatteren har fylt ut ICMJE-skjemaet og oppgir ingen interessekonflikter.

\section{ROBIN SVIGGUM KAVIYANI*}

Indremedisinsk avdeling

Oslo universitetssykehus, Ullevål sykehus

Robin Sviggum Kaviyani er lege i spesialisering.

Forfatteren har fylt ut ICMJE-skjemaet og oppgir ingen interessekonflikter.

\section{ELSE QUIST-PAULSEN}

Mikrobiologisk avdeling

Oslo universitetssykehus, Ullevål sykehus

Else Quist-Paulsen er ph.d., spesialist i infeksjonssykdommer og lege i spesialisering i medisinsk mikrobiologi.

Forfatteren har fylt ut ICMJE-skjemaet og oppgir ingen interessekonflikter.

\section{LUMNIJE DEDI}

Mikrobiologisk avdeling

Oslo universitetssykehus, Ullevål sykehus

Lumnije Dedi er spesialist i mikrobiologi og overlege.

Forfatteren har fylt ut ICMJE-skjemaet og oppgir ingen interessekonflikter.

\section{DAG HENRIK REIKVAM}

Infeksjonsmedisinsk avdeling

Oslo universitetssykehus, Ullevål sykehus

Dag Henrik Reikvam er ph.d., spesialist i infeksjonssykdommer og overlege.

Forfatteren har fylt ut ICMJE-skjemaet og oppgir ingen interessekonflikter.

\section{SYNNE JENUM}

Infeksjonsmedisinsk avdeling

Oslo universitetssykehus, Ullevål sykehus 
Synne Jenum er ph.d., spesialist i infeksjonssykdommer og overlege.

Forfatteren har fylt ut ICMJE-skjemaet og oppgir ingen interessekonflikter.

\section{LINN FOSSHAUG}

Hjertemedisinsk avdeling

Oslo universitetssykehus, Ullevål sykehus

Linn Fosshaug er ph.d. og konstituert overlege i hjertemedisin.

Forfatteren har fylt ut ICMJE-skjemaet og oppgir ingen interessekonflikter.

\section{DONATA BIERNAT}

Avdeling for radiologi og nukleærmedisin

Oslo universitetssykehus, Ullevål sykehus

Donata Biernat er spesialist i radiologi og overlege.

Forfatteren har fylt ut ICMJE-skjemaet og oppgir ingen interessekonflikter.

\section{THOMAS SCHWARTZ}

Indremedisinsk avdeling

Oslo universitetssykehus, Ullevål sykehus

og

Oslo Nye Høyskole

Thomas Schwartz er ph.d., spesialist i infeksjonssykdommer, overlege og førsteamanuensis.

Forfatteren har fylt ut ICMJE-skjemaet og oppgir ingen interessekonflikter.

*Hallvard Berge Pedersen og Robin Sviggum Kaviyani har bidratt i like stor grad til denne artikkelen.

\section{Åpen hjertekirurgi hos en ellers sprek mann ble starten på et halvår med ni innleggelser og et sykdomsforløp dominert av residiverende pleuravæske, deklive ødemer og etter hvert en alvorlig infeksjon. Utredningen og behandlingen var kompleks og krevde multidisiplinær tilnærming.}

En mann i 7o-årene med kjent aortastenose og persisterende atrieflimmer fikk økende

funksjonsdyspné. Ekkokardiografi viste progresjon av aortastenosen, og han ble elektivt operert med åpen hjertekirurgi med innsetting av biologisk aortaklaffventil, lungeveneablasjon og aurikkelreseksjon. Hjerteoperasjonen ble starten på et langvarig sykdomsforløp med residiverende pleuravceske, deklive ødemer og gjentatte innleggelser ved thoraxkirurgisk og senere medisinsk avdeling. Det kliniske bildet ga mistanke om hjertesvikt. Ekkokardiografi og høyresidig hjertekateterisering tre måneder etter inngrepet viste normal systolisk og diastolisk funksjon, velfungerende aortaventil og ingen tegn til restriktivt fylningsmønster eller pulmonal hypertensjon. Fire måneder etter aortaklaffoperasjonen avdekket imidlertid MR-unders $\emptyset$ kelse av hjertet kontrastoppladning $i$ hele perikard. Ved auskultasjon ble det funnet en systolisk bilyd, tolket som gnidningslyd, over hjertet. CRP-verdien hadde under innleggelsene etter hjerteoperasjonen vart lett forhøyet, stort sett mellom 20 og $70 \mathrm{mg} / \mathrm{L}$ ( referanseområde < 4,0). Leukocyttall var innenfor referanseområdet. Pasienten ble gjentatte ganger tappet for pleuravceske, som hadde lavt proteininnhold og var uten mikrobiologiske funn. Tilstanden ble tolket som postkardiotomisyndrom, og man startet behandling med kolkisin $0,5 \mathrm{mg} \times 1$ og metylprednisolon $12 \mathrm{mg} \times 1$. Produksjonen av pleuravceske avtok, og pasienten opplevde bedring av tungpust og allmenntilstand.

Postkardiotomisyndrom kan oppstå etter skade eller kirurgi på hjertet og er kjennetegnet av brystsmerter, tungpust og feber samt perikard- og/eller pleuravæske. Insidensen varierer fra $9 \%$ til $40 \%$, avhengig av diagnostiske kriterier (1). Pasientene har ofte leukocytose og

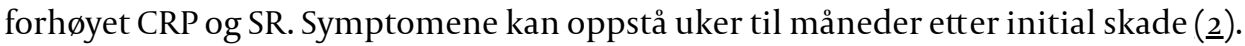
Kolkisin, et antiinflammatorisk medikament som er vist å redusere forekomsten av 
postkardiotomisyndrom etter kirurgi (3,4), og glukokortikoider er anbefalt til behandlingsrefraktære pasienter (1,5). På grunn av det alvorlige kliniske bildet valgte man å starte med begge medikamentene samtidig.

Seks uker etter oppstart av behandling for postkardiotomisyndrom og seks måneder etter aortaklaffoperasjonen, ble pasienten innlagt for niende gang som øyeblikkelig hjelp i medisinsk avdeling. I tillegg til tungpust, hevelser i bena og hjertebank som ved tidligere innleggelser hadde han frostfølelse og smerter i høyre legg og kne. Ved klinisk undersøkelse var han i redusert allmenntilstand. Han var afebril med normalt blodtrykk på 112/80 mm Hg, regelmessig puls på 104 slag/min og oksygenmetning på $95 \%$ uten oksygentilførsel. Det var redusert respirasjonslyd basalt bilateralt som ved pleuravceske, gnidningslyd over prekordiet, lett hevelse i høyre kne og et reaksjonsløst arr etter sternotomi. Til forskjell fra tidligere innleggelser var inflammasjonsparametre betydelig forhøyet med leukocytter 18,2 × 10 $9 / \mathrm{L}\left(3,5-10,0 \times 10^{9}\right), C R P 224 \mathrm{mg} / \mathrm{L}(<4,0)$ og SR $107 \mathrm{~mm}$ $(<12)$. CT thorax viste høyresidig pleuravceske med pleurareaksjon oppfattet som inflammasjon eller infeksjon, samt en mindre, abscessuspekt lesjon i høyre lunge (figur 1). På bakgrunn av det kliniske bildet og radiologisk mistanke om pneumoni med mulig empyem startet man empirisk behandling med cefotaksim $2 \mathrm{~g} \times 3$ for dekning av nosokomial etiologi. Nasofarynksprøve til bakteriedyrkning og PCR-tester for luftveispatogener, inkludert SARS-CoV-2, ga negative resultater.

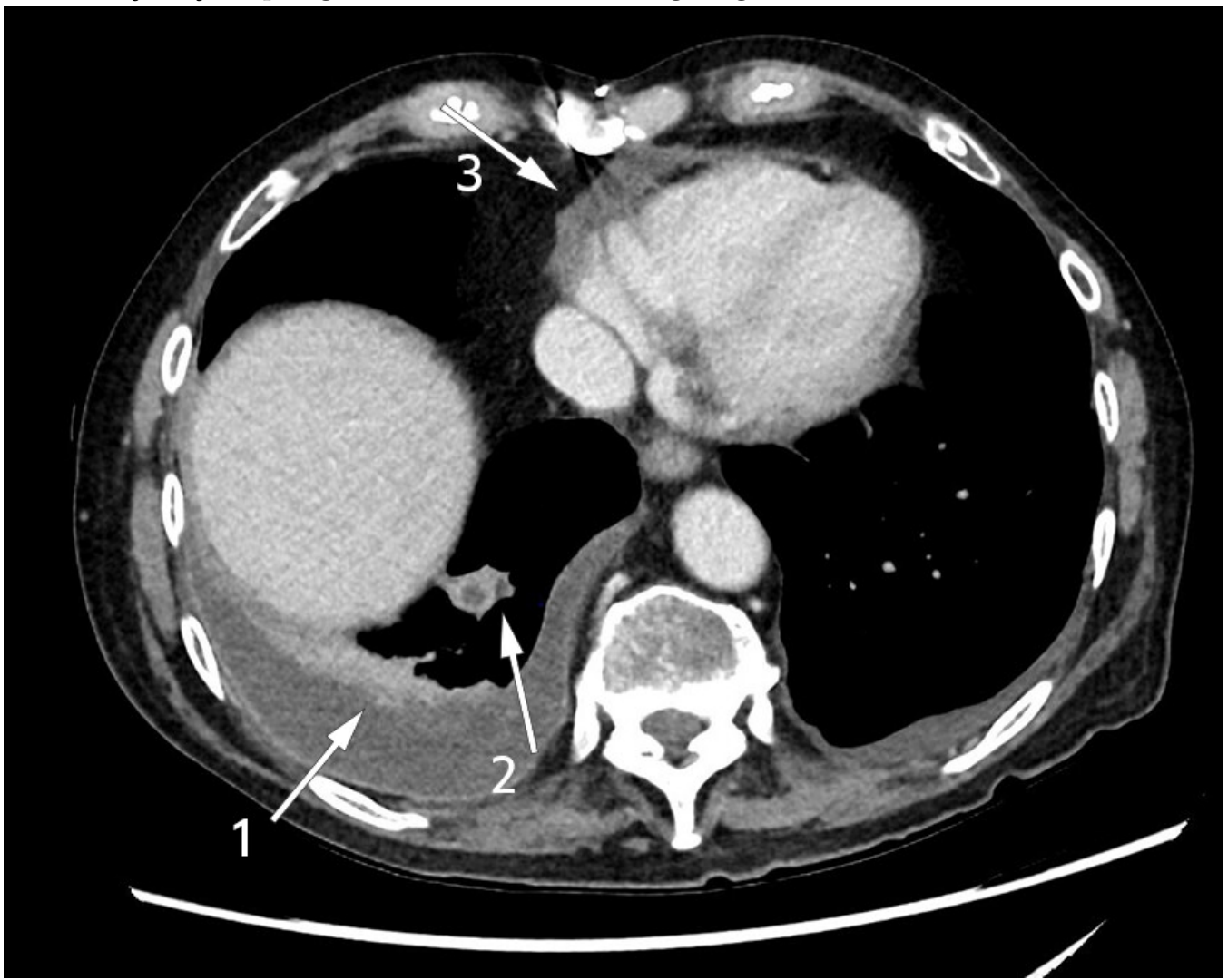

Figur 1 CT thorax med intravenøst kontrastmiddel viser kontrastoppladning i pleura, empyemsuspekt pleuravæske basalt på høyre side (pil 1) og perikardvæske (pil 2) samt en mindre abscessuspekt lesjon (pil 3).

Tre dager etter innleggelsen klaget pasienten over snøvlete tale, og man konstaterte dysartri. CT og MR caput påviste abscessuspekte lesjoner i høyre temporallapp og cerebellarhemisfcere (figur 2). Det var ingen vekst i fire sett blodkulturer. I henhold til norske og internasjonale retningslinjer for behandling av hjerneabscesser ble cefotaksimdosen økt til $4 \mathrm{~g} \times 3$ og metronidazol 1,5 $g \times$ 1 intravenøst lagt til. For å avdekke en eventuell emboluskilde ble det utført transtorakal og transøsofageal ekkokardiografi, som ikke viste holdepunkt for endokarditt. På grunn av forverret dysartri ble det fire dager senere tatt ny MR caput, som viste økende størrelse på begge hjerneabscessene. Påfølgende dag ble det utført abscessdrenasje av nevrokirurg i diagnostisk og terapeutisk øyemed, med evakuering av brunlig puss. Materialet ble sendt til histologisk undersøkelse og dyrkning for å detektere bakterier og sopp. Ved mikroskopi av gramfarget preparat ble det ikke påvist bakterier. Prøvematerialet ble også sendt til $16 \mathrm{~S}$ rDNA-sekvensering. 


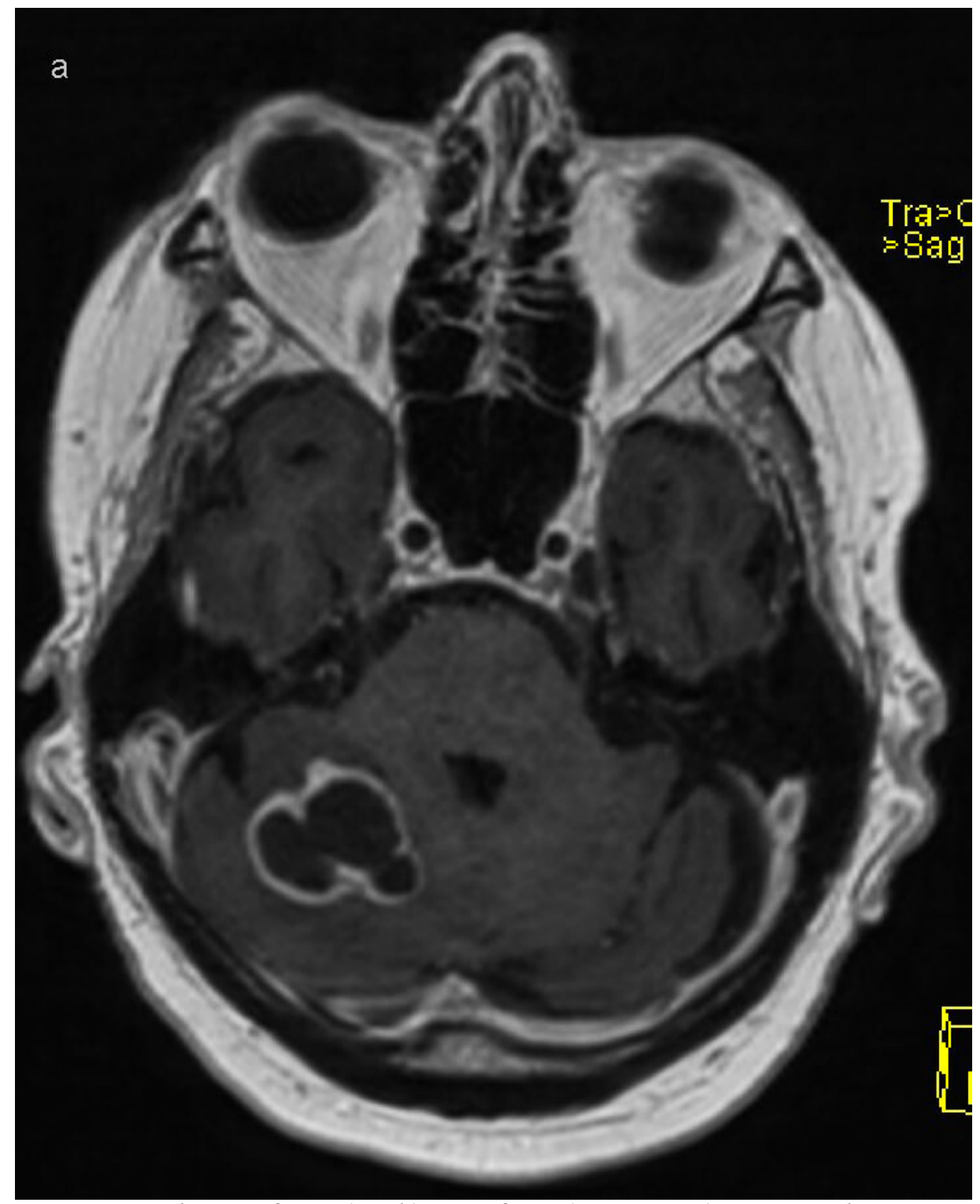

Figur 2 Hjerneabscesser fremstilt ved kontrastforsterket MR. T1-vektet serie med intravenøst kontrastmiddel viser en romoppfyllende prosess i høyre cerebellare hemisfære med sentralt henfall og sirkumferensiell kontrastoppladning.

Abscesser i sentralnervesystemet oppstår i 50 \% av tilfellene som følge av direkte spredning fra nærliggende fokus og i $30 \%$ som ledd i hematogen spredning, mens det i $20 \%$ av tilfellene er ukjent spredningsmønster $(\underline{6})$. Ved abscessdiameter større enn $2,5 \mathrm{~cm}$ anbefales drenering (7.). Abscesser sekundært til lokale fokus har ofte polybakteriell etiologi med munnhule- eller luftveismikrober (므), mens abscesser som følge av hematogen spredning typisk er monobakterielle (므). Som primærdiagnostisk verktøy ved mistanke om intracerebral patologi er CT godt egnet, mens kontrastforsterket MR er nødvendig for å differensiere abscess fra annen patologi. Diagnostisk aspirasjon og biopsi av abscessinnhold bør planlegges i samråd med infeksjonslege, nevrokirurg og mikrobiolog for å sikre riktig og rask håndtering av prøvematerialet. Prøvematerialet til mikrobiologisk diagnostikk skal tas på sterilt glass til mikroskopi, både til Gram- og ZiehlNeelsen-farging, anaerob og aerob dyrkning samt dyrkning av mykobakterier. Hvis mulig ønskes også prøvemateriale på blodkulturmedium. Lumbalpunksjon har liten nytteverdi ved abscesser i sentralnervesystemet og er forbundet med fare for herniering. 
To dager etter abscessdrenasje var det rikelig vekst av Nocardia species pluralis (spp.) i prøve fra abscessinnholdet (figur 3). I tråd med internasjonale anbefalinger ble det startet empirisk

kombinasjonsbehandling med intravenøs trimetoprim-sulfa i høydose, $15 \mathrm{mg} / \mathrm{kg}$ fordelt på 3-4 doser, og imipenem $500 \mathrm{mg} \times 4$ (9), (10). Behandlingen med kolkisin og metylprednisolon ble seponert på grunn av medikamentenes immunsuppressive effekt.

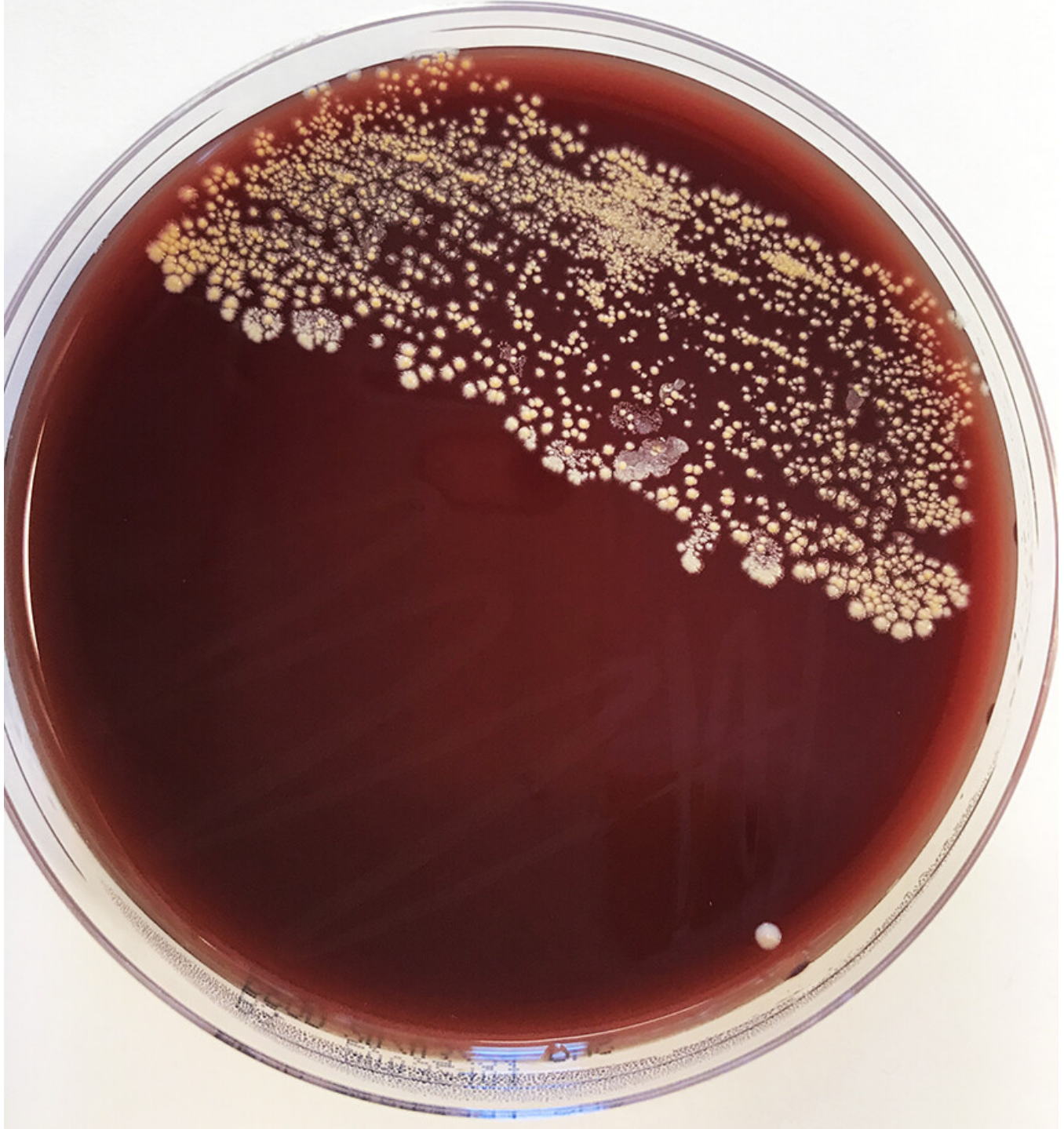

Figur 3 Utsæd fra cerebral abscess på blodagar med pigmenterte kolonier. Foto: Else QuistPaulsen.

Nocardia spp. er strikt aerobe, grampositive, stavformede bakterier. Artene i slekten er ofte langsomtvoksende, og forlenget inkubasjonstid (7-10 dager) kan være nødvendig.

Mikroben vokste på blodagar og var etter kun to dager synlig som kritthvite, tørre kolonier (figur 3). Ved mikroskopi av koloniene så man grampositive staver med filamentøse forgreininger som ved Ziehl-Neelsen-farging var partielt syrefaste (figur 4). Nocardia spp. er miljøbakterier som finnes i jord og vann over hele verden. Av de mer enn 80 ulike Nocardiaartene gir minst 30 sykdom hos mennesker, hvorav de vanligste er N. asteroides-komplekset, N. brasiliensis og N. farcinica (11). Artsidentifikasjon ble utført ved hjelp av massespektrometri (MALDI-TOF, matrix-assisted laser desorption/ionisation-time of flight) og 
ved $16 \mathrm{~S}$ rDNA-sekvensering. MALDI-TOF-massespektrometri har de siste årene revolusjonert arbeidet med identifisering av mikrober. Ved denne metoden fragmenteres og ioniseres mikrobielle proteiner ved laserbestråling, og molekylmassen til de frie ionene detekteres i et vakuumkammer. Mikrobens spektrale proteinmønster sammenliknes med kjente mikroorganismer med etablerte proteinmønstre i en database. Dette gir i de fleste tilfeller en god artsbestemmelse $(\underline{12}, \underline{13})$. I dette tilfellet klarte ikke sekvenseringen å skille mellom N. farcinica, N. kroppenstedtii og N. otitidiscaviarum, men da man ved MALDI-TOFmassespektrometri fikk gjentatte treff på $N$. farcinica, ble denne arten ansett som den mest sannsynlige årsaken til infeksjon hos pasienten. Mikroben ble resistensbestemt ved hjelp av MIC-gradientstrips (minimal inhibitory concentration, minste hemmende konsentrasjon) (Liofilchem) på MH-F-agar (Mueller Hinton fastidious), og ble ansett å være følsom for amoksicillin-klavulanat, imipenem og trimetoprim-sulfa (tabell 1).

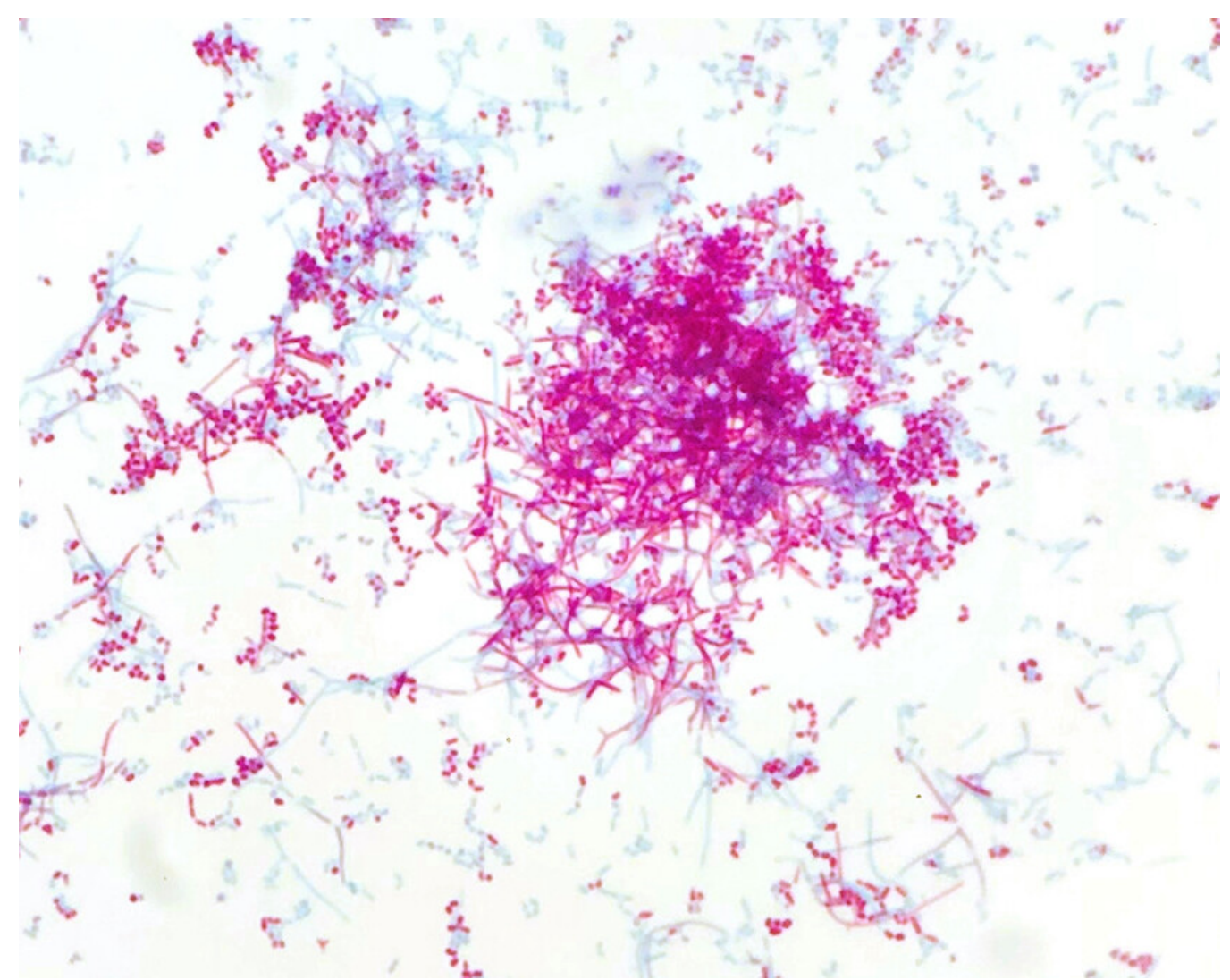

Figur 4 Ziehl-Neelsen-farging av kolonier fra cerebral abscess viser partielt syrefaste staver med filamentøse forgreninger. Foto: Ingvild Elise Orlien.

\section{Tabell 1}

Resistensbestemmelse fra cerebral abscess hos en pasient med nokardiose, utført på MH-Fagar (Mueller Hinton fastidious). Ut fra minste hemmende konsentrasjon (MIC, minimal inhibitory concentration) ble mikroben antatt å være følsom for amoksicillin-klavulanat, imipenem og trimetoprim-sulfametoksazol.

\begin{tabular}{|lr|}
\hline Antibiotikum & MIC $(\mathrm{mg} / \mathrm{L})$ \\
\hline Amikacin & 2,0 \\
\hline Amoksicillin-klavulanat & 1,0 \\
\hline Cefotaksim & $>32$ \\
\hline Ceftriakson & $>32$ \\
\hline Ciprofloksacin & $>32$ \\
\hline
\end{tabular}




\begin{tabular}{|lr|}
\hline Antibiotikum & MIC $(\mathrm{mg} / \mathrm{L})$ \\
\hline Daptomycin & $>256$ \\
\hline Imipenem & 1,0 \\
\hline Klaritromycin & 32 \\
\hline Linezolid & 4,0 \\
\hline Meropenem & 8,0 \\
\hline Minosyklin & 2,0 \\
\hline Moksifloksacin & 2,0 \\
\hline Tetrasyklin & 8,0 \\
\hline Tobramycin & $>256$ \\
\hline Trimetoprim-sulfametoksazol & 0,125 \\
\hline
\end{tabular}

Ved innleggelsen ble det bemerket lett hevelse i høyre kne. Få dager senere tilkom økt omkrets av legg, samt varme, ømhet og smerter ved dorsalfleksjon. For å kartlegge om det forelå flere infeksjonsfokus, ble det utført helkropps-PET-undersøkelse. Denne viste oppladninger rundt høyre kne, i høyre musculus gluteus maximus og nedenfor leverspissen, forenelig med multiple abscesser. Ultralydundersøkelse viste en heterogen oppfylning medioproksimalt for kneleddet og vceskeansamling dorsalt i leggen. Diagnostisk punksjon ble utført, og prøvematerialet sendt til bakteriologisk undersøkelse, hvor man igjen fant vekst av Nocardia spp., identifisert ved MALDITOF-massespektrometri som N. farcinica. Med abscesser i både sentralnervesystemet og bløtvev hadde pasienten per definisjon en disseminert nokardiose.

Nokardiose oppstår hyppigst hos immunsupprimerte pasienter etter inhalasjon av Nocardia-bakterier fra miljøet (므). Dette forklarer at infeksjonen primært etablerer seg i lungene, der den kan forårsake irregulære nodulære, eventuelt kaviterende, lesjoner eller infiltrater, med eller uten pleuravæske (11). Hematogen spredning med disseminert sykdom sees i 20-70 \% av tilfellene, og infeksjonen etablerer seg da hyppig i

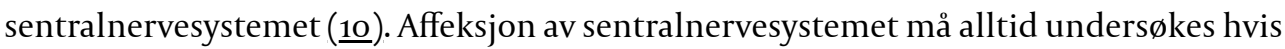
Nocardia spp. identifiseres i andre lokalisasjoner, da dette vil ha konsekvenser for behandlingsvalg og -varighet (1ㅡ). Infeksjon i hud og bløtvev forekommer som ledd i disseminert sykdom og som følge av inokulasjonssmitte. T-celler er vårt viktigste forsvar mot Nocardia spp., og sykdommen sees derfor hyppigst hos transplanterte med immunsuppresjon og personer som behandles med glukokortikoider (9.).

Pasienten responderte langsomt på behandling med trimetoprim-sulfa og imipenem, med avtagende verdier av inflammasjonsmarkører og bedring av dysartri. CT caput etter fem og åtte uker viste regresjon av abscessene. Imidlertid var pasienten svcert plaget med bivirkninger i form av kvalme og diare, og han var flere ganger ncer ved å gi opp behandlingen. Farmakogenetisk analyse påviste defekt CYP2 D19-gen, en mutasjon som gir redusert metabolisme av blant annet sulfametoksazol, og dermed økte bivirkninger. Dosen av trimetoprim-sulfa ble etter tre ukers behandling redusert fra 15 til $9 \mathrm{mg} / \mathrm{kg} /$ døgn, og bivirkningene avtok. Etter åtte ukers intravenøs behandling skiftet man antibiotika til peroral amoksicillin-klavulansyre $500 \mathrm{mg} / 125 \mathrm{mg} \times 3$ og trimetoprim-sulfa 3 tabletter $\times$ 3. Behandlingstiden ble planlagt til ett år, hvorav de siste fire månedene med amoksicillinklavulansyre i monoterapi.

For pasienten ble forløpet langvarig og krevende. Den kompliserte behandlingen av nokardiose, fortsatt residiverende pleuravceske med forverring av postkardiotomisyndrom, ernceringssvikt og depresjon medførte reinnleggelser og måneder på sykehus før rehabilitering var mulig. Snart to år etter hjerteoperasjonen bor pasienten hjemme. Han blir fort sliten, har dårlig matlyst og plages av 
tungpust og hjertebank. Han har utviklet betydelig muskelatrofi, men kan gå turer på opptil én kilometer uten rullator. Han trener daglig og har ukentlig fysioterapi. Han har gått til jevnlige kontroller hos hjerte-, infeksjons- og lungelege samt ernceringsfysiolog.

\section{Diskusjon}

Nokardiose er en uvanlig, opportunistisk infeksjon som gir alvorlig disseminert sykdom. Sentralnervesystemet rammes i særlig grad, men samtlige organsystem kan bli berørt. Nokardiose har ikke patognomoniske presentasjonsformer, men bør mistenkes hos immunsupprimerte pasienter med nodulære eller kaviterende lesjoner i lunge og pussdannende lesjoner i sentralnervesystem, hud og bløtvev. Pasientens nokardiose oppstod sannsynligvis som følge av immunsupprimerende behandling med glukokortikoider for postkardiotomisyndrom og svekket allmenntilstand etter langvarig sykdom. Glukokortikoider har en kjent antiinflammatorisk og immunmodulerende effekt (14). Systemisk behandling gir økt risiko for infeksjoner, og risikoen $\emptyset$ ker med dose og behandlingslengde, alder, underliggende sykdom og annen immunmodulerende behandling $(\underline{15}, \underline{16})$. Det er mer usikkert om kolkisin også bidro til pasientens immunsuppresjon. Virkningsmekanismen for kolkisin er ikke fullstendig kartlagt, og den immunsuppressive effekten er dårligere dokumentert enn for glukokortikoider (17.).

Inokulasjon av Nocardia spp. ved åpen hjertekirurgi er ikke beskrevet i litteraturen. Fravær av lokal infeksjon i operasjonssted både klinisk og ved PET- og CT-undersøkelse, talte også imot dette hos vår pasient. Kontrastoppladning i pleura, pleuravæske og en abscessuspekt lesjon i lunge (figur 1) kunne skyldes både postkardiotomisyndrom og nokardiose, og det var utfordrende å skille inflammasjon fra infeksjon. Selv om vi aldri lyktes i å påvise mikroben i pleuravæske eller luftveier, antar vi at nedre luftveier var primærfokus, med videre hematogen spredning til hjerne og muskulatur i underekstremiteter.

Pasienten fikk antibiotikabehandling i henhold til internasjonale anbefalinger $(9, \underline{10})$. Høydosert trimetoprim-sulfa intravenøst regnes som ryggraden i behandlingen av nokardiose. Ved alvorlig sykdom, som hos denne pasienten, kan det være nødvendig å legge til karbapenemer, gentamicin eller fluorokinoloner, avhengig av resistensbestemmelse (10). Total behandlingstid er 3-12 måneder, avhengig av lokalisasjon, omfang og grad av immunsuppresjon. Sykehistorien er også en påminnelse om at påvisning av enzymdefekter i cytokrom P450-systemet kan ha klinisk betydning både for bivirkninger og behandlingseffekt.

Hos vår pasient var bildediagnostikk og god prøvetagning av hjerneabscessen avgjørende for korrekt diagnose og behandling. Malignitet er en viktig differensialdiagnose ved hjerneabscess, og det bør derfor også sendes prøver på formalin til patologisk undersøkelse. For denne pasienten ble rett diagnose stilt etter dyrkning, men i tillegg bør $16 \mathrm{~S}$ rDNA-sekvensering direkte på prøvematerialet alltid vurderes. PCR kan detektere bakterier som er krevende å dyrke, påvise døde mikrober hos pasienter som har fått behandling med antibiotika forut for prøvetagning, og gi rask diagnose. Ved mistanke om Nocardia spp. har rask identifikasjon stor betydning, da resistensmønster varierer på artsnivå, og empirisk behandling vil dermed kunne tilpasses $(\underline{18}, \underline{19})$.

KONKLUSJON

Sykehistorien illustrerer at nokardiose bør mistenkes ved abscesser og subakutt infeksjon hos pasienter under immunsupprimerende behandling, inkludert behandling med glukokortikoider. Utredning av nokardiose krever bredt faglig samarbeid, og vi anbefaler at spesialister med erfaring i behandling av tilstanden involveres. Nokardiose kan kureres, men krever langvarig og høydosert antibiotikabehandling. 
Pasienten har gitt samtykke til at artikkelen blir publisert.

Artikkelen er fagfellevurdert.

\section{LITTERATUR}

1. Lehto J, Gunn J, Karjalainen P et al. Incidence and risk factors of postpericardiotomy syndrome requiring medical attention: The Finland postpericardiotomy syndrome study. J Thorac Cardiovasc Surg 2015; 149:1324-9. [PubMed][CrossRef]

2. Lehto J, Kiviniemi T. Postpericardiotomy syndrome after cardiac surgery. Ann Med 2020; 52: 243-64. [PubMed][CrossRef]

3. Imazio M, Belli R, Brucato A et al. Efficacy and safety of colchicine for treatment of multiple recurrences of pericarditis (CORP-2): a multicentre, double-blind, placebo-controlled, randomised trial. Lancet 2014; 383: 2232-7. [PubMed][CrossRef]

4. Imazio M, Trinchero R, Brucato A et al. COlchicine for the Prevention of the Post-pericardiotomy Syndrome (COPPS): a multicentre, randomized, double-blind, placebo-controlled trial. Eur Heart J 2010; 31: 2749-54. [PubMed][CrossRef]

5. Tamarappoo BK, Klein AL. Post-pericardiotomy Syndrome. Curr Cardiol Rep 2016; 18: 116. [PubMed] [CrossRef]

6. Brouwer MC, Tunkel AR, McKhann GM et al. Brain abscess. N Engl J Med 2014; 371: 447-56. [PubMed] [CrossRef]

7. Mamelak AN, Mampalam T], Obana WG et al. Improved management of multiple brain abscesses: a combined surgical and medical approach. Neurosurgery 1995; 36: 76-85, discussion 85-6. [PubMed] [CrossRef]

8. Kommedal $\emptyset$, Wilhelmsen MT, Skrede $S$ et al. Massive parallel sequencing provides new perspectives on bacterial brain abscesses. J Clin Microbiol 2014; 52:1990-7. [PubMed][CrossRef]

9. Restrepo A, Clark NM. Nocardia infections in solid organ transplantation: Guidelines from the Infectious Diseases Community of Practice of the American Society of Transplantation. Clin Transplant 2019;33: e13509. [PubMed][CrossRef]

10. Sorell TC, Mitchell DH, Iredell JR et al. Nocardia Species. I: Mandell, Douglas and Bennett's Principles and Practice of Infectious Diseases. 8. utg. Philadelphia, PA: Elsevier, Saunders, 2015: 285363.

11. Wilson JW. Nocardiosis: updates and clinical overview. Mayo Clin Proc 2012; 87: 403-7. [PubMed] [CrossRef]

12. Rollag H, Müller F, Tønjum T. Medisinsk mikrobiologi. 4. utg. Oslo: Gyldendal forlag, 2019.

13. Nyberg E, Nyborg K, Liberg AM et al. MALDI-TOF MS: En mikrobiologisk revolusjon. Bioingeniøren 2015; 50:23-6.

14. Chatham WW, Kimberly RP. Treatment of lupus with corticosteroids. Lupus 2001; 10:140-7. [PubMed][CrossRef]

15. Stuck AE, Minder CE, Frey FJ. Risk of infectious complications in patients taking glucocorticosteroids. Rev Infect Dis 1989; 11: 954-63. [PubMed][CrossRef]

16. Youssef J, Novosad SA, Winthrop KL. Infection risk and safety of corticosteroid use. Rheum Dis Clin North Am 2016; 42: 157-76, ix-x. [PubMed][CrossRef]

17. Larsson S, Rønsted N. Reviewing Colchicaceae alkaloids - perspectives of evolution on medicinal chemistry. Curr Top Med Chem 2014; 14: 274-89. [PubMed][CrossRef]

18. Glupczynski Y, Berhin C, Janssens M et al. Determination of antimicrobial susceptibility patterns of Nocardia spp. from clinical specimens by Etest. Clin Microbiol Infect 2006; 12: 905-12. [PubMed] [CrossRef]

19. Tan YE, Chen SC, Halliday CL. Antimicrobial susceptibility profiles and species distribution of medically relevant Nocardia species: Results from a large tertiary laboratory in Australia. J Glob Antimicrob Resist 2020; 20: 110-7. [PubMed][CrossRef]

Publisert: 13. desember 2021. Tidsskr Nor Legeforen. DOI: 10.4045/tidsskr.21.0163

Mottatt 27.2.2021, første revisjon innsendt 1.7.2021, godkjent 31.8.2021.

Publisert under åpen tilgang CC BY-ND. Lastet ned fra tidsskriftet.no 26. april 2023. 